\title{
PENGARUH METODE LATIHAN DRILL TERHADAP KETEPATAN SMASH DALAM PERMAINAN BOLA VOLI KLUB TARUNA MERAH PUTIH SEMARANG \\ Arif Rachman Alhakim ${ }^{1)}$, Galih Dwi Pradipta'), Muh Isna Nurdin ${ }^{3)}$ \\ 1,2,3Pendidikan Jasmani Kesehatan dan Rekreasi, Universitas PGRI Semarang Email: novasetyorini509@gmail.com
}

\begin{tabular}{l}
\hline Artikel Info \\
\hline Koresponden penulis : \\
Arif Rachman Alhakim \\
Email: novasetyorini509@gmail.com \\
$\square$ Diterima 11 November 2021 \\
$\square$ Direview 18 Januari 2022 \\
$\square$ Disetujui 29 Januari 2022 \\
$\square$ Dipublikasi 31 Januari 2022
\end{tabular}

Kata Kunci: Latihan drill, Ketepatan smash, Bola Voli

Keywords: Drill practice, Smash accuracy, Volleyball

\begin{abstract}
Abstrak
Penelitian ini adalah eksperimen dengan desain One-Group Pretestposttest Design.Teknik analisis data dalam penelitian ini menggunakan statistik uji-t. Instrument menggunakan test smash dari Stanley (M. Yunus 1991;299). Populasi dalam penelitian adalah anak laki-laki usia 15-18 tahun pemain Klub Taruna Merah Putih Semarang. Teknik pengambilan sampel adalah total sampling. Hasil perhitungansSetelah diberikan latihan drill mengalami peningkatan dimana hasil rata-rata pretest sebesar 23,20 dan posttest sebesar 33,93 serta diperoleh nilai $t_{\text {hitung }}$ pretest dan posttest adalah sebesar $-10,761$ dengan sig $=0,000$ dan nilai $t_{\text {tabel }}$ adalah 2,144 maka dapat disimpulkan $\mathrm{H}_{1}$ diterima, dan dapat dijelaskan terdapat perbedaaan peningkatan ketepatan smash pemain klub bola voli Taruna Merah Putih Semarang antara sebelum dan setelah diberikan latihan drill. Berdasarkan analisis hasil penelitian dan pembahasan di atas, dapat disimpulkan bahwa ada peningkatan akurasi ketepatan smash Pemain klub bola voli Taruna Merah Putih Semarang melalui metode latihan drill.
\end{abstract}

\begin{abstract}
This research is an experimental design with One-Group Pretestposttest Design. The data analysis technique in this study uses t-test statistics. The instrument uses a test smash from Stanley (M. Yunus 1991; 299). The population in this study were boys aged 15-18 years, players of the Semarang Red and White Youth Club. The sampling technique is total sampling.The results of calculations After being given drill exercises have increased where the average result of the pretest is 23.20 and the posttest is 33.93 and the t-count value of the pretest and posttest is $-10,761$ with sig $=0.000$ and the ttable value is 2.144, it can be concluded that $H 1$ is accepted, and It can be explained that there is a difference in the increase in the accuracy of the smash accuracy of the volleyball club Taruna Merah Putih Semarang between before and after being given drill practice.Based on the analysis of the results of the research and discussion above, it can be concluded that there is an increase in the accuracy of the smash accuracy of the volleyball club Taruna Merah Putih Semarang through drill training methods.
\end{abstract}




\section{PENDAHULUAN}

Bola voli merupakan suatu permainan beregu yang dimainkan oleh dua tim yang saling berhadapan dan masing masing terdiri dari enam pemain. Permainan bola voli sangat terkenal dimasyarakat, dimulai dari kalangan atas sampai kalangan bawah sudah tidak asing lagi dengan nama bola voli. Sering dijumpai di daerah daerah tertentu permainan bola voli ini dimainkan banyak orang, muda maupun dewasa. Kebanyakan orang memainkan bola voli ini untuk mengisi waktu luang, mencari keringat, dan bahkan untuk prestasi yang meringankan mereka untuk melanjutkan belajar kejenjang pendidikan yang lebih tinggi.

Bola voli menjadi cabang olahraga permainan yang menyenangkan karena dapat beradaptasi dengan kondisi yang mungkin timbul di dalamnya,dapat dimainkan dengan jumlah pemain yang bervariasi seperti voli pantai dengan jumlah pemain 2 orang, dan permainan dengan jumlah 6 orang yang biasa sering digunakan. Olahraga bola voli dapat dimainkan disegala bentuk lapangan seperti rumput, kayu, pasir, ataupun lantai buatan, serta dapat dilakukan di gedung Untuk dapat memainkan permainan bola voli bagi anak-anak usia muda tidaklah mudah. Butuh waktu dan proses yang panjang agar keterampilan gerakan anak dalam bermain bola voli dapat dikuasai dengan baik. Hal ini dikarenakan permainan bola voli merupakan permainan yang menuntut adanya kecepatan, kelentukan, dan kelincahan bagi pemain sendiri.

Permainan bola voli juga memiliki estetika, saat melakukan lompatan, pukulan dan variasi serangan. Hal ini dapat terjadi jika suatu pemain sudah dapat menguasai selurah teknik - teknik pada bola voli. sudah dijelaskan bahwa teknikteknik bola voli yaitu pasing, servis, blok, smash. Smash pada permainan bola voli adalah hal terpenting saat melakukan serangan untuk mendapatkan point demi point saat pertandingan.

Maka dari itu, untuk menjadi pemain voli yang andal, selain mengetahui permainan, juga menguasai ketrampilan dasarnya. Ketrampilan dasar yang harus dimiliki setiap pemain antara lain servis, mengumpan, membendung, dan smash. Setelah menguasai semua teknik dasar bola voli, pemain dapat dengan mudah menempatkan posisinya didepan atau dibelakan.Dibutuhkan kerjasama dan kekompakan setiap pemain dalam timnya 


\begin{tabular}{|c|c|}
\hline Journal STAND: Sports and Development \\
http://jurnal.unipasby.ac.id/index.php/stand/about/submissions \\
jurna Surabaya
\end{tabular}

untuk memperoleh kemenangan. Dari hasil pengamatan atau observasi dilapangan masih banyak yang harus di perbaiki dalam melakukan smash. Masih banyak ditemui kesalahan-kesalah yang terjadi saat melakukan smash.Seperti ketepatan pukulan, langkah kaki, power pukulan, dan timing pukulan.

Ketepatan pukulan,masih banyaknya atlet pada saat melakukan pukulan smash sering kali tidak tepat pada sasaran,hal itu mungkin dipengaruhi oleh metode yang digunakan pada saat latihan.sehingga perlu adanya metode yang baru yang tepat untuk meningkatkan hasil ketepatan pukulan tersebut. Langkah kaki,pada tahap ini juga sering terjadi kesalahan, kesalahan pada tahap ini juga akan sangat menentukan keberhasilan melakukan smash, baik dari langkah awal ataupun hasil akhirnya .

Power pukulan,hanya ada beberapa atlet saja yang memiliki power pukulan yang baik pada saat melakukan smash.ini juga tidak lepas dari pengaruh langkahan tadi.jadi langkahan juga dapat mempengaruhi hasil pukulan smash. Timing pukulan,disini juga sangat penting untuk menentukan hasil pukulan smash yang baik,timing disini adalah pada saat melakukan pukulan smash di udara dengan perkenaan bola yang tepat pada tangan.
Pada atlet taruna merah putih semarang juga masih ada masalah dalam urusan timing tersebut.

Dari masalah ini kemudian membuat penelitian untuk memperbaiki pukulan smash yang efektif dilakukan pada anak-anak klub Taruna Merah Putih dengan menggunakan metode latihan Drill.Berdasarkan penjelasan diatas maka penulis tertarik untuk menulis sebuah penelitian tentang "Pengaruh metode latihan drill terhadap hasil ketepatan smash dalam Permainan Bola Voli Klub Taruna Merah Putih (TMP) klipang Semarang”.

\section{METODE PENELITIAN}

Penelitian ini adalah eksperimen dengan desain One-Group Pretest-posttest Design.Teknik analisis data dalam penelitian ini menggunakan statistik uji-t. Instrument menggunakan test smash dari Stanley (M. Yunus 1991;299). Populasi dalam penelitian adalah anak laki-laki usia 15-18 tahun pemain Klub Taruna Merah Putih Semarang. Teknik pengambilan sampel adalah total sampling

\section{HASIL DAN PEMBAHASAN}

Data yang dikumpukan dan dianalisis adalah data tes ketepatan smash dengan (pretest dan posttest) yang diperoleh dari sampel penelitian secara langsung. 


\begin{tabular}{|c|c|}
\hline Unipa Sumabaya & Journal STAND: Sports and Development \\
http://jurnal.unipasby.ac.id/index.php/stand/about/submissions \\
jurnal.stand@unipasby.ac.id
\end{tabular}

Berdasarkan hasil pretest diketahui bahwa ketepatan smash pemain klub bola voli

Taruna Merah Putih Semarang sebelum diberi perlakuan metode latihan drill adalah sebagai berikut:

Tabel 1. Data Pretest

\begin{tabular}{ccc}
\hline No & Kategori & Hasil \\
\hline 1 & Mean & 33,93 \\
2 & Median & 34 \\
3 & Modus & 34 \\
4 & Skor max & 40 \\
5 & Skor min & 29 \\
6 & Standar deviasi & 2,93 \\
\hline
\end{tabular}

Tabel 2. Data Postest

\begin{tabular}{ccc}
\hline No & Kategori & Hasil \\
\hline 1 & Mean & 23,20 \\
2 & Median & 22 \\
3 & Modus & 21 \\
4 & Skor max & 29 \\
5 & Skor min & 19 \\
6 & Standar deviasi & 3,12 \\
\hline
\end{tabular}

Dari hasil perhitungan analisis data diperoleh data pretest diketahui bahwa ketepatan smash pemain klub bola voli Taruna Merah Putih Semarang Tabel 4.1 diperoleh nilai mean atau rata-rata 23,20, nilai median 22, nilai modus 21 , skor maksimal 29, skor minimal 19 dan nilai simpangan baku (std.deviasi) 3,12. Sesudah data pretest di peroleh selanjutnya dilakukan treatment dengan latihan drill. Setelah treatmen selesai dilakukan maka selanjutnya dilakukan postest untuk mengetahui apakah ada pengaruh latihan drill terhadap ketepatan smash pemain klub bola voli Taruna Merah Putih Semarang. Adapaun data postest setelah diberi perlakuan atau treatmen sebagai berikut:

Tabel 3. Deskripsi Data

\begin{tabular}{|c|c|c|c|c|c|c|c|c|}
\hline & $\begin{array}{l}\text { Ran } \\
\text { ge }\end{array}$ & Min & Max & $\begin{array}{l}\mathrm{Su} \\
\mathrm{m}\end{array}$ & $\begin{array}{l}\mathrm{Me} \\
\text { an }\end{array}$ & $\begin{array}{l}\text { Std } \\
\text { Eror }\end{array}$ & $\begin{array}{c}\text { Std. } \\
\text { Deviat } \\
\text { ion }\end{array}$ & $\begin{array}{c}\text { Varian } \\
\text { ce }\end{array}$ \\
\hline PRETEST & 10 & 19 & 29 & 348 & $\begin{array}{r}23 \\
20\end{array}$ & ,776 & 3,125 & 9,029 \\
\hline POSTEST & 11 & 29 & 40 & 509 & $\begin{array}{r}33 \\
93 \\
\end{array}$ & ,759 & 2,939 & 8,638 \\
\hline
\end{tabular}

Dari hasil perhitungan analisis data diperoleh data postest ketepatan smash pemain klub bola voli Taruna Merah Putih Semarang tabel 4.2 diperoleh nilai mean atau rata-rata 33,93 mengalami peningkatan dari hasil pretest, nilai median 34 , nilai modus 34 , skor maksimal 40, skor minimal 29 dan nilai simpangan baku (std.deviasi) 2,93. Setelah data pretest dan data postest diperoleh selanjutnya data dari Hasil penelitian akan diuraikan dan dihitung dengan menggunakan SPSS 20. maka dapat dijelaskan bahwa mean/ratarata ketepatan smash pemain klub bola voli Taruna Merah Putih Semarang sebelum diberi latihan drill adalah 23,20 dengan simpangan baku 3,12 hasil nilai maksimal 29 dan hasil nilai minimal atau 
terkecil 19. Mean/rata-rata ketepatan smash pemain klub bola voli Taruna Merah Putih Semarang setelah diberi latihan drill adalah 33,93 dengan simpangan baku 2,93 hasil nilai maksimal 40 dan hasil nilai terkecil atau minimal 29.

Berdasarkan tabel diatas dan hasil pembahasan data deskriptif pretes dan postest ketepatan smash pemain klub bola voli Taruna Merah Putih Semarang diatas maka dapat disajikan ilustrasi gambar berbentuk diagram batang, sebagai berikut:

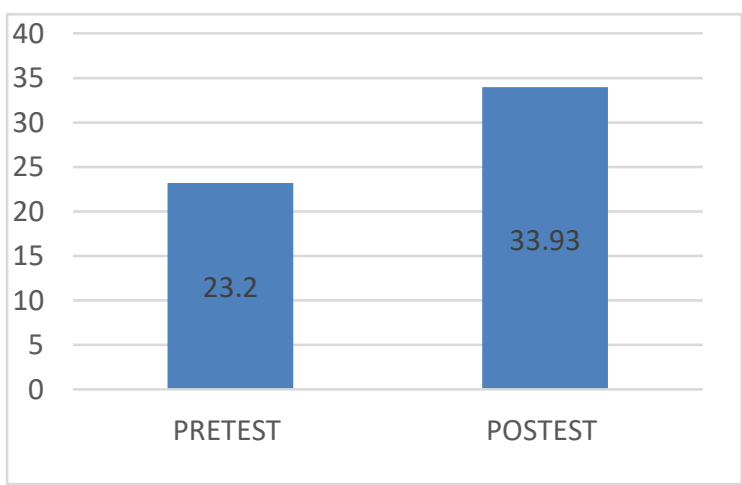

Gambar 1. Diagram batang rata-rata akurasi ketepatan smash

\section{SIMPULAN DAN SARAN}

Setelah diberikan latihan drill mengalami peningkatan dimana hasil ratarata pretest sebesar 23,20 dan posttest sebesar 33,93 serta diperoleh nilai thitung pretest dan posttest adalah sebesar -10,761 dengan sig $=0,000$ dan nilai $t_{\text {tabel }}$ adalah 2,144 maka dapat disimpulkan $\mathrm{H}_{1}$ diterima, dan dapat dijelaskan terdapat perbedaaan peningkatan ketepatan smash pemain klub bola voli Taruna Merah Putih Semarang antara sebelum dan setelah diberikan latihan drill. Berdasarkan analisis hasil penelitian dan pembahasan di atas, dapat disimpulkan bahwa ada peningkatan akurasi ketepatan smash Pemain klub bola voli Taruna Merah Putih Semarang melalui metode latihan drill.

Saran bagi pemain supaya lebih meningkatkan akurasi ketepatan teknik dasar smash. Bagi pelatih diharapkan Bagi pelatih diharapkan dapat memberikan metode latihan drill untuk meningkatkan peningkatan ketepatan smash pemain klub bola voli Taruna Merah Putih Semarang.

\section{DAFTAR PUSTAKA}

ABD RAHMAN, T. A. D. J. U. (2019). Pengaruh Latihan Drill Statis Terhadap Peningkatan Ketepatan Pukulan Smash Dalam Permainan Bola Voli. Skripsi, 1(832414007).

ANO, A. Z. (2019). Pengaruh Latihan drill terhadap ketepatan smash dalam permainan Bola Voli pada Siswa SMP Negeri 1 Telaga. Skripsi, 1(832412049).

Beuttelstahl, Dieter. 2013. Belajar Bermain Bola Volley.Bandung: Pionir Jaya. 


\begin{tabular}{|c|c|}
\hline Journal STAND: Sports and Development \\
unttp://jurnal.unipasby.ac.id/index.php/stand/about/submissions \\
jurnal.stand@unipasby.ac.id
\end{tabular}

Danang, YMD. 2012. Pengaruh latihan memukul bola di gantung terhadap ketepatan smash peserta ekstrakurikuler bola voli di SMP N 1 Panjaitan Kulon Progo. Skripsi. Universitas Negeri Yogyakarta.

Febriani, Y., \& Rifki, M. S. (2020). Pengaruh Metode Drills For GameLike Situation Terhadap Kemampuan Passing Bawah Atlet Bolavoli. Jurnal Stamina, 3(6), 481-498.

Ismoko, A. P., \& Sukoco, P. (2013). Pengaruh metode latihan dan koordinasi terhadap power tungkai atlet bola voli junior putri. Jurnal Keolahragaan, 1(1), 1-12

Sugiyono.2013. Cara Mudah Menyusun Skripsi, Tesis, dan Disertasi.Bandung: CV Alfabeta.

Yunus, M. 1991. Olahraga Pilihan Bola Voli. Jakarta: Depdikbud Direktorat Jendral Pendidikan Tinggi.

Wahyu,VRW. 2017. Pengaruh latihan membidik target terhadap kemampuan akurasi smash peserta esktrakurikuler bola voli di SMPN 2 Berbah Sleman. Skripsi. Universitas Negeri Yogyakarta.
Widiastuti, Dr. M. Pd. 2011. Tes dan pengukuran Olahraga. Jakarta: PT Bumi Timur Jaya.

Sutrisno, Hadi. 2002. Metodologi Research. Yogyakarta: Andi Offside. Suharsimi, A. 2013.Dasar-dasar Evaluasi Pendidikan. Jakarta: Paragonatama Jaya. 